\title{
Intergenerational representations of schistosomiasis in endemic area, Jaboticatubas, Minas Gerais
}

\author{
Celina Maria Modena, Virginia Torres Schall/ ${ }^{+}$ \\ Laboratório de Educação em Saúde, Centro de Pesquisa René-Rachou-Fiocruz, Av. Augusto de Lima 1715, 31190-002 \\ Belo Horizonte, MG, Brasil
}

The analysis of the intergenerational process of disease/health representations constitutes a requisite for the construction of projects and health education interventions. The objective of this work is to describe the meaning attributed to schistosomiasis in the family context. Twenty-one residents of an endemic area were interviewed. The interviews were submitted to content analysis. The results demonstrated different representations of the disease by the children, parents and grandparents. This paper discusses the differences in these representations and its impact in schistosomiasis control programs.

Key words: schistosomiasis - intergenerational representation - family context

Morbidity and the spatial expansion of schistosomiasis have demonstrated that the conceptual explanatory models of the disease/health process and interventional actions need to incorporate explanatory dimensions that go beyond biomedical models (Schall 1998). In this perspective, Gazzinelli et al (1998) emphasize the importance of investigating the social and cultural process of the determination of different health risks. This interpretation overpasses the meaning of the biological perception of diseases, leading to a comprehension of a more complete reality, including the historicity of the phenomenon. In this light, Schall (1998) propose an interpretative and interventional model in schistosomiasis health education which considers the transmission and maintenance of the disease as interaction between material conditions and the social relations of production. In other words, as Trindade (1996) points out "health/disease, are conceptions constructed in social spaces delimited by the relations established by the production, beliefs, values, access to the official health services and education, besides other factors".

Considering this perspective and breaking through the compartmentalized interpretation of the disease/health process, Diniz et al. (2003) developed studies in Jaboticatubas, state of Minas Gerais, which have demonstrated that there is no similarity between the representation of students and the reality of schistosomiasis in the area. According to the authors, these representations are anchored on the information passed on through parents and teachers, based on former health campaigns dated from the time when schistosomiasis was a more serious health problem.

Financial support: Fapemig, CNPq

This article is part of the research of the first author Postdoctoral Program.

${ }^{+}$Corresponding author: vtschall@cpqrr.fiocruz.br

Received 25 May 2006

Accepted 26 June 2006
As a result, the knowledge of the representation of the family about the process of health/disease of schistosomiasis is fundamental because it allows for the reestablishment of relations and representations constructed by the subject in his social-historical context, in the perspective of the family, community and school. The family is responsible for the primary socialization and the school for the secondary socialization (Berger \& Luckmann 1985). Nonetheless, one hopes that the family and the school propitiates its pupils with a continuous socialization, characterized by Nicolaci-da-Costa (1985) as "the proximity between values, attitudes and used of language in which the subject socialized finds in his family and school environment". The integration of the individual in diverse groups occurs through the process of socialization which, according to Berger and Luckmann (1985) initiates with primary socialization, which is the first one experimented by the individual.

In intergenerational studies two central problems stand out (Troll \& Bengston 1979): (1) the socialization, or, in other words, the transmission of characteristics through generations; (2) the interpersonal relations between family members from different generations.

Thus, considering the relations and interactions between health and education in specific social-historical context, this research has the general objective to identify the social representation of schistosomiasis in the family context in order to produce subsidies for educators to integrate these representations in the learningteaching process and health actions.

\section{METODOLOGY}

Context and social representation - The context of the social representation theory in studies of social phenomenon are discussed by diverse authors, such as Farr (1993), which emphasizes that it is only worth it to study a social representation if it is relatively spread out inside a culture in which the study is done. This is the case of schistosomiasis in Jaboticatubas where health control actions have been taking place since 1953 organized by the Ministry of Health. The studies conducted by Massara and Schall (2004) in the area should be underlined. 
Social representations may be understood as a category of thought which a society uses it to elaborate and express its reality. Durkheim (1898) was the first to use the term collective representations, defined as categories of thought that are connected to social facts, being in themselves social facts, which may also be observed and interpreted. Social representations are a set of real phenomenon which behave in specific forms and may exert over individuals a type of coercion leading them to act in a determined way.

According to Spink (1989), the term social representation was rescued by Moscovici in social psychology based on the idea of collective representation, already presented by Durkheim.

For Moscovici (1978), social representations may be defined as a system of values, notions and practices, which has a double vocation. First, it installs an order which allows individuals to orientate themselves in the social and material environment and dominate it. Secondly, it secures a communication between members of a community, proposing to its members a code to nominate and classify, in a unique way, the parts of their world, their individual or collective history. All representations emerge from our need to transform what is strange into something familiar.

According to the author, working with the prerequisite that knowledge and the experience individuals have of the world depend on the form in which they come together with other beings, things and people that are present in their surroundings, or in other words, how they experience something.

The meaning that is attributed to the disease, perceived subjectively by "ill" individuals, is significant when it is affirmed real by other members of the society. As Alves (1993) states it, the meaning is only real when it is originated from the common sense. Schutz (1962) also observed that the world in daily life functions as a code of reference for individuals, and lastly Alves (1993) remind us that every meaning is only logical for the individual because it is socially and culturally legitimated by its fellow members.

Consequently, it is in social space that people interpret a given episode of disease, considering determined cultural patterns which are, in the last instance, social creations, formed by definitions and interpretations constructed intersubjectively. Only within given coordinates established by the intersubjective world of the common sense is that the experience of disease will be objective to others (Alves 1993).

Procedures - There is a multiplicity of methodological design for a study of social representations. Therefore, this investigation will search different instruments to evaluate the social representation of schistosomiasis in the family context.

The instruments utilized were naturalistic observations, semi-structured interviews and focal groups in the family context. Some theoreticians of the Social Representation Theory (Spink 1993, 1994, De Rosa 1993) support a methodological triangulation as a strategy of approximating to the reality which one hopes to study.
In agreement with Marconi and Lakatos (1985), the observation is considered here as a data collection technique that has the objective to bring the researcher closer to the investigated reality, focalizing on a specific social context.

Some authors (Debus 1988, Roso 1997) argue that the use of focal group methodology is adequate in qualitative studies, and others present its utilization in a specific area of health research. It is also a technique that permits certain flexibility, since it opens space for the construction of "mini-groups" in which questions that need a more profound approach may be analyzed.

The focal group technique is considered a procedure of data collection that offers some advantages, such as: in a short space in time there is the possibility to obtain a vast array of information; the wealth of the information acquired through the interaction is vast; the emotional involvement in the net of transferences and counter-transferences is great; among other advantages.

The semi-structured interview is chosen due to its flexibility and possibility to obtain information through direct contact with subjects. In this way, a "conversation with finality" is proposed as states Minayo (2000). This instrument supposes the utilization of a script which is minimaly structured and also considers the interaction of the researcher/object, as a data also to be analyzed.

The interviews were semi-structured and divided into three units of context, term loaned from Bardin (1994), in maybe a non-conventional form - (1) the person; (2) the disease; and (3) the family. In each of these contextual units, a series of questions were related and served as a form of orientation for the development of interviews.

This work was approved by the ethical committee of CPqRR-Fiocruz.

\section{RESULTS AND DISCUSSION}

The representations of schistosomiasis, in this phase of the study, may be considered as preliminary, since more in depth analysis will be conducted a posteriori. One may conclude that distinct representations exist in the family context according to generations (children, parents, and grandparents).

The first generation, the grandparents, when interviewed about the disease supplied much information, with richness in details, evidencing a considerable amount of knowledge in relation to the symptoms and treatment of the disease. All of them affirmed that they had the disease, and some were hospitalized, demonstrating that the perceived morbidity made schistosomiasis familiar to this social segment. In the time in which they were infected with the disease, it was endemic and with high prevalence in the area. Nowadays, they believe that schistosomiasis is eradicated since they do not observe classical clinical cases, as demonstrated in the speech bellow:

Look, I'm a very practical man. I only believe in what I see. I've seen many people with "xistosa". I've had two brothers that had this dreadful thing. He had to take out the spleen because he had a big tummy. Today there isn't anything like this. I only believe in what I see (male, 71 years old). 
The second generation, the parents, reflects a situation of the disease where it is experimented in different ranges. They affirm that when a certain apathy or tiredness comes over them, with some difficulty to work, the older family members send them to a medical service, since they seemed to present "xistose". The parents affirm that the only seriousness of a case is when a disease "messed up" the functional capability and the utilization of the body. In general terms, this segment held the notion that the disease is associated to their productive capacity. They question the asymptomatic cases denominated as serious, believing that successive treatments diminished the gravity of the agent.

When the person has "xistose" she gets worn-out. A weary person can't do anything, it gets in the way. A tired person, good gracious! (...) For a person to do something she has to be up for it, be well. (female - 46 years old).

For the representation of health/disease, in terms of transmission and treatment, within children and teenagers (third generation), it is clear that the majority of statements affirm that there is little knowledge about the disease. Viruses and bacteria are commonly pointed out as agents in the transmission cycle of different helminthes. In the representation of the disease, the interviewees reveal a contradiction between what is learned within family relations with what is learned to them at school or observed in their daily life.

Furthermore, the majority of the interviews demonstrated a great influence of the representations of the grandparents over their grandchildren's representation, as pointed out in the interview bellow:

I was going to do my science homework (...) and I asked my mother (...) she said that "xistose" gives people pain in the legs (...) the teacher didn't said this (...) my grandfather explained it to me (...) he knows things. (male, twelve years old)

Many studies have shown the importance of the participation and influence of grandparents in the life of their grandchildren, such as: behavior, personality and psychosocial conscience (Roberto \& Stroes 1992, Franks et al. 1993). Grandparents are seen as important figures in many social aspects (ex: respect, influence in the behavior, participation in family gatherings, among others) and also in the personal formation of the children (ex: source of knowledge, sense of perspective, emotional bonding) (Sanders \& Trygstad 1993). Other studies have demonstrated that the meanings that what young people attributed to their grandparents were also important, such as historians, confidents, substitute parents and friends.

In general, it was observed that it was in the collective space that people interpret the process of health/disease of schistosomiasis. This interpretation is constructed intersubjectively through cultural patterns.

The family context is fundamental in the construction of meaning, since it is through this social institution that man acquires his behavior, values, norms and attitudes. This socialization is only possible through an emotional bond of identification of the person with other people which are important to him.

The secondary socialization introduces the individual into new sectors of the objective world of his society. It occurs through the interiorization, by the child, of new institutionalized worlds. This interiorization does not occur as a pattern, since it is dependent on the social and material conditions of production and distribution of knowledge.

It is important to underline that these models of socialization play different roles in the construction of identity. While in primary socialization the child interiorizes the world of their parents as being the world, that is, as being the only world existent; in secondary socialization it is the institutional context that will be perceived and evaluated. In this way, the internalization only completes itself when there is identification, when the subject absorbers the roles and attitudes of other social actors.

In layers of society with low income, there are classical studies which show the distance among values and practices that children find between their family context and school. (Nicolaci-da-Costa 1988). Silva (1996) states that there is a social-cultural barrier between school and family and that it produce a true sociological cleavage.

Consequently, nowadays a great challenge presents itself in the field of education: the integration between the instances that act on children and teenagers, specifically the school and family. Brought to new generations, not only knowledge and abilities, but also the ability to incorporate values and to participate in their society consolidate the access to citizenship. The interaction between school and family should be approached in a perspective which leads to the comprehension of everyday life, where leaning and formation of individuals take place.

In the perspective of the pedagogy of autonomy, Freire (1996) affirms that it is necessary to read the understanding of underprivileged groups which do not produce abstract discourses, but plastic discourses, rich in metaphors. They do not mold concepts: they tell facts. It is necessary to establish a dialogue in which one devises the group to think its own history, in this case, the relation with schistosomiasis. One of the tasks of health educators is to stimulate new comprehension of the context. As Freire (2002) states, the educative process may be prescriptive or dialogical. The first is the act of transference of knowledge, while the second is the act and method of actions which may transform reality.

Considered as a central point the relationship between health/disease and family, from subjective and socio-historical contexts, new conceptual paradigms and intervention actions need to be constructed (Vasconcelos 2000, Cecconello 2003, Serapioni 2005).

Diverse areas of knowledge, specifically psychology, sociology and history should place themselves as a starting point for new reflection and interdisciplinary dialogues (Wagner 2002, Nogueira et al. 2003, Petrini \& Cavalcanti 2005).

This approach contributes for the comprehension of a complex and multireferential reality, like the dimensions of contemporary family and shistosomiasis, in specific social spaces. 


\section{REFERENCES}

Alves PC 1993. A experiência da enfermidade: considerações teóricas. Cad Saúde Públ 9: 263-271.

Bardin L 1994. Análise de Conteúdo, Edições 70, Lisboa.

Berger P, Luckmann T 1985. A Construção Social da Realidade, 20th ed., Vozes, Petrópolis, 248 pp.

Cecconello AM, De Antoni C, Koller SH 2003. Práticas educativas, estilos parentais e abuso físico no contexto familiar. Psic em Estudo, Maringá 8: 45-54.

De Rosa AS 1993. Social representations and attitudes: problems of coherence between the theoretical definition and procedure of research. Ongoing Prod Soc Represent 2: 115.

Debus M 1988. Manual para Excelência en la Investigación Mediante Grupos Focales, University of Pennsylvania, Porter/Novelli.

Diniz MCP, Braga RB, Schall VT 2003. As representações sociais da esquistossomose de escolares de área endêmica de Minas Gerais. Ensaios 5: 28-47.

Durkheim E 1898. Représentations individualles et représentations collectives. Rev Métaph Morale VI: 273-302.

Farr RM 1993. Common sense, science and social representations. Public Understanding Sci 2: 111-122.

Franks LY, Hughes JP, Phelps LH, Willians DG 1993. Intergerational influences on midwest college students by their grandparents and significant elders. Educat Gerontol 19: 265-271.

Freire P 1996. Pedagogia da Autonomia: Saberes Necessários à Prática Educativa, 29th ed., Paz e Terra, São Paulo.

Freire P 2002. Ação Cultural para a Liberdade, 9th ed., Paz e Terra, São Paulo.

Gazzinelli A, Gazzineli MF, Cadete MM 1998. Sociocultural aspects of schistosomiasis mansoni in an endemic area in Minas Gerais, Brazil. Cad Saúde Públ 14: 841-849.

Marconi MA, Lakatos EM 1985. Técnicas de Pesquisa, Atlas, São Paulo, 205 pp.

Massara CL, Schall VT 2004. A pedagogical approach of schistosomiasis - An experience in health education in Minas Gerais, Brazil. Mem Inst Oswaldo Cruz 99: 113-119.

Minayo MCS 2000. O desafio do Conhecimento: Pesquisa Qualitativa em Saúde, 7th ed., Hucitec, São Paulo.

Moscovici S 1978. A Representação Social da Psicanálise, Zahar, Rio de Janeiro.

Nicolaci-Da-Costa AM 1985. "Privação cultural”, "privação lingüistica" e família. In Vekho G, Figueira SA, Cultura da Psicanálise, Brasiliense, São Paulo, p. 147-168.
Nicolaci-da-Costa AM 1988. O processo de modernização da sociedade e seus efeitos sobre a família contemporânea. Anais da $18^{\mathrm{a}}$ Reunião Anual da Sociedade Brasileira de Psicologia, Ribeirão Preto, p. 101-107.

Nogueira MA, Romanelli G, Zago N 2003. Família \& Escola: Trajetórias de Escolarização em Camadas Médias e Populares, 2nd ed., Vozes, Petrópolis, 183 pp.

Petrini JC, Cavalcanti VRS 2005. Família, Sociedade e Subjetividades: Uma perspectiva Multidisciplinar, Vozes, Petrópolis, $256 \mathrm{pp}$.

Roberto KA, Stroes J 1992. Grandchildren and grandparents: roles, influences ande relationships. Intern J Aging and $\mathrm{Hu}$ man Developt 34: 227-239.

Roso A 1997. Grupos focais em psicologia social: da teoria à prática. Psico 28: 155-169.

Sanders G, Trygstad D 1993. Strengths in the grandparentgrandchildren relationship. Activities, Adaptation and Aging 17: 43-53.

Schall V T 1998 . An interactive perspective of health education for the tropical disease control: the schistosomiasis case. Mem Inst Oswaldo Cruz 93: 51-58.

Schutz A 1962. Collected Papers. Vol. I. The Problem of Social Reality, Martinus Phijhoff, The Hangué.

Serapioni M 2005. O papel da família e das redes primárias na reestruturação das políticas sociais. Ci Saúde Coletiva 10: 243-253.

Silva P 1996. Pais-professores: uma relação em que uns não são mais do que outros? Educação, Sociedade \& Culturas 6: 179-190.

Spink MJP 1989. As Representações Sociais e suas Aplicações em Pesquisa na Área da Saúde, PUC, São Paulo.

Spink MJP 1993. O Conhecimento no Cotidiano: as Representações Sociais na Perspectiva da Psicologia Social, Brasiliense, São Paulo, 313 pp.

Spink MJP 1994. Desvendando as teorias implícitas: uma metodologia de análise das representações sociais. In Guareschi P, Jovchelovitch S, Textos em Representações Sociais, Vozes, Petrópolis, p. 117-145.

Trindade ZA 1996. Representação social: "modo de conhecer" no cenário da saúde. In Trindade ZA, Camino C, Cognição e Juizo Moral: Coletâneas da ANPEPP. ANPEPP 6: 45-59.

Troll L, Bengston L 1979. Generations in the family. In WRHurr, R Hill, F Nye, IL Reiss (eds), Contemporary Theories about the Family, The Free Press, New York.

Vasconcelos EM 2000. A priorização da família nas políticas de saúde. Rev APS 2: 20-28.

Wagner A 2002. Família em Cena: Tramas, Dramas e Transformações, Vozes, Petrópolis, 188 pp. 